\title{
SYMBIOTIC EFFECTIVENESS IN NODULATED RED CLOVER
}

\section{FURTHER STUDIES ON INHERITANCE OF INEFFECTIVENESS IN THE HOST \\ P. S. NUTMAN}

Rothamsted Experiment Station, Harpenden, Herts, and Division of Plant Industry, C.S.I.R.O., Canberra

\section{INTRODUCTION}

Received 28.v.56

THE effectiveness of symbiosis between nodule bacteria and the leguminous plant is usually measured by the growth of the nodulated plant in the absence of combined nitrogen in the root medium. It is thus a measure of the nitrogen fixing capacity of the nodule and ranges from full effectiveness which supports normal plant growth to complete ineffectiveness in which no nitrogen is fixed.

Earlier work has shown that effectiveness depends upon heritable factors in the bacteria and in the host plant. In a previous paper (Nutman, $1954 b$ ) a recessive host factor $\left(i_{1}\right)$ was described which causes complete ineffectiveness in nodules produced by a strain of bacteria which otherwise gives an effective response in the host. Also, among crosses between effectively responding plants described in the first paper of this series (Nutman, r 954a, table 3) some families segregated a larger number of ineffectively responding plants than occurred in unselected material. This paper will concern the further genetic analysis of ineffectiveness in one of these families (fam. 50). The influence of bacterial strain variation on the response of plants of differing genetic constitution will also be considered. Previous papers may be consulted for details of origin of plant and bacterial material and of experimental techniques.

\section{OBSERVATIONS, RESULTS AND DISCUSSION}

The parents of family 50 were selected in an experiment carried out in I94I with commercial late-flowering Montgomeryshire red clover inoculated with Rhizobium trifolii, Rothamsted strain A, and grown on agarin test tubes under bacteriologically controlled conditions. One parent referred to below as $\mathrm{P}_{3}$ (to distinguish it from the ineffective plants $P_{1}$ and $P_{2}$ described previously) responded completely ineffectively with this strain; the other parent responded effectively. The ineffective parent had 25 nodules of small size (mean length $0.67 \mathrm{~mm}$.) and the effective parent only three nodules of unusually large average size $(2 \cdot 76 \mathrm{~mm}$.).

The progenies of the cross between these plants and of subsequent 
crosses were tested in bacteriologically controlled culture in test tubes inoculated in each case with the effective bacterial strain A.

\section{(i) Genetic analysis of families derived from the ineffective $P_{3}$}

The results are given in table I using the five size grades of host response previously described. These comprise grade $o$, which

TABLE I

Response of progenies derived from the original ineffective plant $P_{3}$ to inoculation with strain $A$

\begin{tabular}{|c|c|c|c|c|c|c|c|}
\hline \multirow{2}{*}{$\begin{array}{l}\text { Family } \\
\text { number }\end{array}$} & \multirow{2}{*}{$\begin{array}{c}\text { Cross type } \\
\text { I, ineffective ; E, effective }\end{array}$} & \multicolumn{5}{|c|}{$\begin{array}{l}\text { Response of progeny : } \\
\text { no. of plants in each grade }\end{array}$} & \multirow{2}{*}{$\begin{array}{l}\text { Corrected } \\
\text { ratios } \\
\text { I:E }\end{array}$} \\
\hline & & o (I) & I & 2 & 3 & $4(E)$ & \\
\hline $\begin{array}{l}50 \\
\text { I } 49, \text { I } 50 \\
\text { I } 5 \text { I } \\
\text { I } 52 \\
\text { I } 53 \\
\text { I } 54-166 \\
\text { I } 67-17 \text { I } \\
\text { I } 72-\text { I } 8 \text { I } \\
\text { I } 82\end{array}$ & $\begin{array}{l}\text { Parental cross : } \mathrm{P}_{3} \times \text { unrelated effective } \\
\text { Backcross of } \mathrm{E}\left(\mathrm{F}_{1}\right) \times \mathrm{E} \text { (Parent) } \\
\text { Backcross of } \mathrm{I}\left(\mathrm{F}_{1}\right) \times \mathrm{E}(\text { Parent) } \\
\text { Sib cross : } \mathrm{E}\left(\mathrm{F}_{1}\right) \times \mathrm{E}\left(\mathrm{F}_{1}\right) \\
\text { Sib cross : } \mathrm{I}\left(\mathrm{F}_{1}\right) \times \mathrm{E}\left(\mathrm{F}_{1}\right) \\
\mathrm{E} \times \mathrm{E} \text { and } \mathrm{E} \times \mathrm{I} \text { Sib crosses in } \mathrm{F}_{2} \text { and } \mathrm{F}_{3} \\
\text { Sib crosses : } \mathrm{I}\left(\mathrm{F}_{3}\right) \times \mathrm{I}\left(\mathrm{F}_{3}\right)(\mathrm{I}) \\
\text { Sib crosses : } \mathrm{I}\left(\mathrm{F}_{3}\right) \times \mathrm{I}\left(\mathrm{F}_{3}\right)(2) \\
\\
\mathrm{I}\left(\mathrm{F}_{3}\right) \text { self } .\end{array}$ & $\begin{array}{r}4 \\
38 \\
12 \\
21 \\
10 \\
103 \\
97 \\
79 \\
2\end{array}$ & $\begin{array}{r}\text { I } \\
7 \\
\mathrm{I} \\
2 \\
3 \\
\mathrm{I} \\
5 \\
4 \\
\mathrm{I} \\
\mathrm{I} \\
\cdots\end{array}$ & $\begin{array}{r}3 \\
8 \\
3 \\
7 \\
1 \\
12 \\
\cdots \\
7 \\
7\end{array}$ & $\begin{array}{r}5 \\
\mathrm{I} 6 \\
6 \\
7 \\
2 \\
52 \\
\cdots \\
\mathrm{I} 2 \\
\ldots\end{array}$ & $\begin{array}{r}20 \\
34 \\
6 \\
\text { I } 5 \\
4 \\
60 \\
\ldots \\
33 \\
\ldots\end{array}$ & 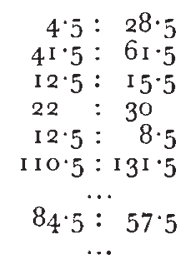 \\
\hline $\begin{array}{l}\text { I } 83 \\
184, \text { I } 85 \\
\text { I } 86-\text { I } 90 \\
\text { I } 91-198 \\
\text { I } 99-20 \text { I } \\
\\
202 \\
203\end{array}$ & $\begin{array}{l}\text { I }\left(\mathrm{F}_{2}\right) \text { outcrossed to unrelated } \mathrm{E} \\
\mathrm{I}\left(\mathrm{F}_{3}\right) \text { outcrossed to unrelated } \mathrm{E} \\
\text { Offspring of fam. I } 84 \text { inter se } . \\
\text { Offspring of fam. I } 85 \text { inter se }: \\
\text { Backcross of } \mathrm{E} \text { (fam. I } 84) \times \mathrm{I} \text { parent } \\
\text { Backcross of I (fam. I } 86) \times \mathrm{E} \text { (fam. I } 83 \text { ) } \\
\text { Backcross of I (fam. I } 86) \times E \text { (fam. I } 83 \text { ) }\end{array}$ & $\begin{array}{l}\cdots \\
\cdots \\
30 \\
26 \\
73 \\
\text { I } 8 \\
\cdots\end{array}$ & $\begin{array}{l}\cdots \\
\ldots \\
\text { I3 } \\
\text { I } 3 \\
20\end{array}$ & $\begin{array}{r}\text { I } \\
3 \\
29 \\
22 \\
\text { I } 3\end{array}$ & $\begin{array}{r}4 \\
8 \\
27 \\
60 \\
14\end{array}$ & $\begin{array}{l}24 \\
38 \\
38 \\
28 \\
19\end{array}$ & 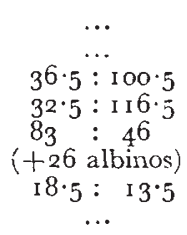 \\
\hline
\end{tabular}

consists of completely nitrogen starved plants indistinguishable from uninoculated controls; grade 4 which contains plants fully effective in response to inoculation and showing no symptoms of nitrogen deficiency; grades I, 2 and 3 show intermediate degrees of effectiveness. For the purpose of estimating segregating ratios in progenies containing intermediately graded plants, the plants classed in grade I are regarded as half effective and half ineffective and those in grades 2 , 3 and 4 as effective. This classification is based upon a study of the relation of these gradings to the normal distributions of dry weight in large populations of effective and ineffective plants (see Nutman, I954 $a$, p. 4I).

Family $5^{0}$ is shown in the table as a parental cross with later generations conventionally designated.

The response of the parental cross was itself mixed, I4 per cent. falling into the ineffective category. The original $\mathrm{P}_{3}$ plant was short lived so that backcrosses could not be made with it, and of the four 
wholly ineffective $F_{1}$ progeny of family $5^{0}$ only one survived for further crossing, with the result that crosses among ineffectives could not be carried out at this stage. However, effective progeny of the primary cross and the single surviving $F_{1}$ ineffective were backcrossed to the effective parent (fams. I 49, I $5^{\circ}, I_{5}$ I) and these gave rise in each kind of cross to approximately equal numbers of the contrasted types. $F_{1}$ segregants in family $5^{0}$ were also crossed among themselves (fam. I 52) and a single family (fam. I 53) was raised from unlike parents. In both of these crosses effectives and ineffectives again segregated in equal numbers. Later crosses among $\mathrm{F}_{2}$ and $\mathrm{F}_{3}$ effectives and between effectives and ineffectives in $F_{2}$ and $F_{3}$ were carried out with substantially the same result as in earlier generations, about equal numbers of effectives and ineffectives appearing in the progenies (fams. I 54-I 66).

The ineffective segregants in these crosses generally did not long survive transplanting from agar into soil. It was not until the $\mathrm{F}_{3}$ generation that more than one surviving ineffective reached the stage of flowering and setting seed. These on intercrossing (fams. I67-I8I) gave progenies which were either wholly ineffective or about one-third effective. Among the crosses between $\mathrm{F}_{3}$ effectives and between plants of differing response, some of the families segregated a much higher proportion of effectives than others. The relatively simple ratios seen in many of these crosses suggest that simple genetic factors are involved, their segregation being obscured by other hereditary influences.

Outcrosses were next carried out between $\mathrm{F}_{2}$ and $\mathrm{F}_{3}$ ineffectives and unrelated effective plants (fams. 183-185). These were wholly effective and demonstrated the recessive nature of ineffectiveness in the foregoing progenies. Effectives from families 184 and I 85 crossed among themselves produced one ineffective in every four examined. The first group of families was very variable giving a $\chi_{[4]}^{2}$ of 24.3 $(\mathrm{P}=\mathrm{O} \cdot \mathrm{I})$ in spite of a good average agreement with a $\mathrm{I}: 3$ ratio; families I9I-I 98 were more homogeneous $\left(\chi_{[7]}^{2}=\right.$ II 8 , n.s. $)$. This suggests that ineffectiveness in these families is unifactorial.

Ineffectives àfter outcrossing were again difficult to raise to maturity; of seven planted out into soil only four survived and of these three failed to flower. Backcrosses involving effectives from family 184 and an ineffective from family 186 gave variable results due to the segregation of albinos, the symbiotic response of which could not be determined. The number of albinos corresponded approximately to that required to restore the observed ratio to unity as shown in the table. There seems little doubt therefore that the departure from I : I in these families is due to linkage between the dominant effective factor and an albino factor. Backcrosses were also made between ineffectives from family 186 and effectives from family i 83. One of these (fam. 202) gave the expected equal numbers of effectives and ineffectives. The other (fam. 203), however, was 
wholly effective; this may be because the ineffective parent in this case owed its ineffectiveness to factors other than the primary gene which appears to be segregating in these families.

In the previous paper (Nutman, I954b) data were presented to show that the expression of ineffectiveness due to a factor $i_{1}$ was subject to modification by an independent suppressor gene $m_{1}$ in such a way that the genotype $i_{1} i_{1} m_{1} m_{1}$ was effective. The failure to account for the segregations found in families I49-166 in terms of a single factor suggests that some kind of genetic modification of the action of a primary gene may also be concerned here.

TABLE 2

The influence of inbreeding on effectiveness

\begin{tabular}{|c|c|c|c|c|c|c|c|}
\hline \multirow{2}{*}{$\begin{array}{l}\text { Number of } \\
\text { families }\end{array}$} & \multirow{2}{*}{$\begin{array}{c}\text { Number of } \\
\text { plants }\end{array}$} & \multirow{2}{*}{$\begin{array}{l}\text { Wright's * } \\
\text { coeff. of } \\
\text { inbreeding } \\
\text { per cent. }\end{array}$} & \multicolumn{5}{|c|}{ Grading distribution (per cent.) } \\
\hline & & & o & I & 2 & 3 & 4 \\
\hline Pedigree I & & & & & & & \\
\hline$\cdots$ & II 6 & outcrosses & 4 & $\cdots$ & 2 & 7 & 87 \\
\hline & I95 & $25^{\circ} \mathrm{O}$ & 3 & 4 & 14 & 20 & 59 \\
\hline Pedigree 2 & & & & & & & \\
\hline 6 & 228 & outcrosses & $\mathrm{I}$ & 2 & 6 & Io & $8 \mathrm{I}$ \\
\hline 2 & $\begin{array}{r}59 \\
66\end{array}$ & $\begin{array}{l}3 \cdot 1 \\
6 \cdot 3\end{array}$ & 3 & $\begin{array}{l}3 \\
3\end{array}$ & $\begin{array}{r}4 \\
21\end{array}$ & $\begin{array}{l}17 \\
18\end{array}$ & $\begin{array}{l}73 \\
58\end{array}$ \\
\hline 2 & 36 & 15.6 & 5 & & $3^{1}$ & I7 & 47 \\
\hline 12 & 266 & $25 \cdot 0$ & 3 & 3 & 14 & 24 & $5^{6}$ \\
\hline Pedigree 3 & & & & & & & \\
\hline$\cdots$ & 63 & outcrosses & .. & 2 & IO & 23 & 65 \\
\hline 2 & 20 & $12 \cdot 5$ & $\cdots$ & $\ldots$ & 5 & 35 & 60 \\
\hline 5 & 55 & $25 \cdot 0$ & 7 & I3 & I 8 & 34 & 28 \\
\hline $\mathbf{I}$ & 30 & $37 \cdot 5$ & 7 & 7 & 10 & 43 & 33 \\
\hline
\end{tabular}

* Wright, 1922 .

A suppressor gene will tend to give rise to a preponderance of effectives in crosses either among effectives or between ineffectives and effectives. In families of ineffective parentage such a factor will lead to a proportion of families in which about equal numbers of effectives and ineffectives segregate in progenies which otherwise would be pure breeding for ineffectiveness. This explanation is not at variance with the results obtained although a number of wholly effective families would have been expected to occur in the number examined.

Alternative hypotheses would be that more than one simple ineffective gene is concerned or that effectiveness is multifactorial and shows incomplete dominance. In the former case a minority of wholly effective families would be found in the effective $\times$ effective and effective $\times$ ineffective crosses, the rest segregating about equal 
numbers of effectives and ineffectives. On this hypothesis also, the ineffective $x$ ineffective crosses would be either wholly ineffective, or give rise to variable proportions of effectives.

If multifactorial inheritance is concerned, some data on the effect of inbreeding are relevant. These are set out in table 2 and refer to three separate pedigrees (unrelated to any of the above material) in which no clear segregation of ineffectives occurred. The results show that inbreeding leads to a progressive reduction in effectiveness in each pedigree, the proportion of plants falling into the intermediate categories increasing but the number of fully ineffective plants remaining fairly small. Some of the ineffectives appearing in families I49-I 66

TABLE 3

Relation between the genes $\mathrm{i}_{\mathbf{1}}$ and ie

\begin{tabular}{|c|c|c|c|c|c|c|c|}
\hline \multirow{2}{*}{$\begin{array}{l}\text { Family } \\
\text { number }\end{array}$} & \multirow{2}{*}{ Cross type } & \multicolumn{5}{|c|}{ Response of progeny } & \multirow{2}{*}{$\begin{array}{l}\text { Corrected } \\
\text { ratios }\end{array}$} \\
\hline & & 0 & I & 2 & 3 & 4 & \\
\hline 204 & $\mathrm{P}_{1} \times \mathrm{P}_{3} ; \mathrm{I} \times \mathrm{I}$ & $\ldots$ & $\ldots$ & $\ldots$ & $\ldots$ & I I & $\ldots$ \\
\hline 205 & $\begin{array}{l}\text { Derived } i_{1} i_{1} \times \mathrm{P}_{3} ; \mathrm{I} \times \mathrm{I} \\
\text { Derived }{ }_{1} \mathrm{i}_{1} \times \text { derived ie.ie; } \\
\quad \mathrm{I} \times \mathrm{I}\end{array}$ & $\cdots$ & $\cdots$ & $\cdots$ & $\ldots$ & 4 & $\ldots$ \\
\hline $\begin{array}{l}206-210 \\
206-210\end{array}$ & $\begin{array}{l}\text { Expt. (I) } \\
\text { Expt. (2) }\end{array}$ & $\begin{array}{r}14 \\
4\end{array}$ & $\begin{array}{l}15 \\
\ldots\end{array}$ & $\begin{array}{l}2 \mathrm{I} \\
\ldots\end{array}$ & $\begin{array}{l}13 \\
25\end{array}$ & $\begin{array}{r}18 \\
107\end{array}$ & $\begin{array}{c}21 \cdot 5: 59 \cdot 5 \\
4: 1^{2}\end{array}$ \\
\hline $\begin{array}{l}211-214 \\
215-218 \\
219\end{array}$ & $\begin{array}{l}F_{2} \text { of } \mathrm{i}_{1} \times \mathrm{ie} \text { cross }: \\
\underset{\mathrm{E}}{\mathrm{E} \times \mathrm{E}} \quad \cdot \\
\mathrm{I} \times \mathrm{I}\end{array}$ & $\begin{array}{l}52 \\
57 \\
30\end{array}$ & $\begin{array}{l}3 \\
5 \\
1\end{array}$ & $\begin{array}{l}5 \\
7 \\
1\end{array}$ & $\begin{array}{l}\text { I } 4 \\
23 \\
\cdots\end{array}$ & $\begin{array}{l}21 \\
27 \\
\cdots\end{array}$ & $\begin{array}{c}53 \cdot 5: 4 I^{1 \cdot 5} \\
59 \cdot 5: 59^{\circ} 5 \\
\ldots\end{array}$ \\
\hline
\end{tabular}

are probably of polygenic origin but the results in table 2 suggest that the number of such ineffectives would be too few to obscure the segregation of major genes.

A detailed reconsideration of segregation in the $F_{1}$ to $F_{4}$ generations in the light of these hypotheses will not be attempted; the families are too small to allow critical tests to be made, but the evidence seems sufficient to justify the tentative designation of a recessive gene (ie) for ineffectiveness in this material. Information on nodule size within these families is given below and bears upon the identity of the gene ie and its possible modification by other host factors.

(ii) The relation between the factors $i_{1}$ and ie

The results of breeding tests made to determine the relation between the factors $i_{1}$ and $i e$ are given in table 3 .

That these factors are neither identical nor allelic is suggested by the absence of ineffectives in two small families (fams. 204, 205) raised from crosses between the original ineffective selections $P_{1}$ and $\mathrm{P}_{3}$, and between a derived $i_{1}$ homozygote and $\mathrm{P}_{3}$. However, later 
hybrids (fams. 206-210) between derived $i_{1}$ and derived ie plants were not completely effective, the proportion of ineffectives appearing in the progenies varying from test to test as shown in table 3 . This may indicate either that some change has taken place in the bacterial strain or that other factors for ineffectiveness, susceptible to environmental influences, are segregating in these lines. As no indication of change in the bacterial strain could be inferred from other experiments carried out subsequently (see table 7), selections were made to test the second hypothesis. The results (fams. 2II-2I9) of tests carried out at different times show that crosses among effectives, and between effectives and ineffectives, segregate approximately in the ratio of 7 ineffectives to 9 effectives. The single cross between ineffectives bred true so that there are other hereditary influences contributing to ineffectiveness in this material. Although the data are consistent with a 7:9 segregation, they are insufficient to determine whether the genes $i_{1}$ and $i e$ are independently inherited. Further information on the independent action of these genes is given below in a section dealing with the number and size of nodules found in these families.

\section{(iii) Characteristics of the ie plants}

Homozygotes of type ie classified into grade o were indistinguishable in top size and in the colour and appearance of their leaves from normal plants inoculated with ineffective strains of bacteria, or from plants of the $i_{1}$ line inoculated with strain $\mathrm{A}$, or from uninoculated control plants. At harvest (IOo days) the cotyledons and older leaves had withered and the youngest or two youngest leaves were very small and pale yellow green. The seedling root systems of ie plants were normal in appearance and nodules formed readily upon them.

\section{(iv) The number and size of nodules on ie plants}

With respect to nodule size and abundance $i e$ ineffectives differed from plants inoculated with ineffective strains and from $i_{1}$ plants. In general ie nodules were variable in number and were not more numerous than nodules on heterozygotes, nor were they exclusively of small size. Two ie ineffectives are figured in plate $\mathrm{I}, a$ and $b$; they illustrate the range found both in number and size and may be compared with a normal effective $(d)$.

The mean number of nodules occurring on ie plants showing either ineffective, intermediate or effective responses are set out in table 4 with $i_{1}$ material included for comparison.

Among plants of families bred directly from $\mathrm{P}_{3}$ without outcrossing the mean nodule number shows a maximum for plants of intermediate response. This trend becomes more marked among segregating families after outcrossing; plants of intermediately effective response forming twice as many nodules as completely ineffective plants. The general increase in numbers after outcrossing may reflect the use of rather abundantly nodulating plants as effective parents. 
These families thus show a consistent tendency in their nodulation with strain $A$ for both the lcast effective and the most effective plants to produce the fewest nodules, and the intermediate grades the most. This pattern appears to be specific for strain A since with other strains of varying degrees of effectiveness the homozygous line gives the normal ineffective maximum and effective minimum as shown in tablc 4. This is brought about by a marked reduction in the number of nodules produced on plants of increasingly effective response and not by an increase in numbers of nodules on ineffectives.

These relations are in striking contrast to those shown in table 4 for $i_{1}$ plants upon which very large numbers of nodules were formed with strain $A$ (group 4) and fewer nodulcs with strains giving an effective response (group 5).

\section{TABLE 4}

Average numbers of nodules on plants of ineffective, effective and intermediate response in ie and $\mathrm{i}_{1}$ lines

\begin{tabular}{|c|c|c|c|c|c|}
\hline & o & I & 2 & 3 & 4 \\
\hline $\begin{array}{l}\text { (s) ie lines (fams. } 154^{-1} 78 \text { ) before outcrossing, } \\
\text { inoculated istrains }\end{array}$ & 64 & 72 & 95 & 83 & 70 \\
\hline $\begin{array}{l}\text { (2) ie lincs after outcross (fams. I9I-198) } \\
\text { inoculated A strains }\end{array}$ & 97 & I 40 & 181 & 138 & 119 \\
\hline $\begin{array}{l}\text { (3) ie lines (fams. I6r-1 } 71 \text { ) inoculated with } \\
\text { effective and ineifective strains un- } \\
\text { related to strain } A\end{array}$ & 65 & 78 & 26 & 59 & $3^{6}$ \\
\hline (4) homozygous $i_{1}$ lines inoculated strain $\mathrm{A}$ & II 3 & $\ldots$ & . & & \\
\hline $\begin{array}{l}\text { (5) homorggous } i_{2} \text { lines inoculated with } \\
\text { effective and ineffective strains un- } \\
\text { related to strain A }\end{array}$ & 130 & $\ldots$ & I I I & 64 & $4^{8}$ \\
\hline
\end{tabular}

On nodule size also these two factors have divergent effects, as can be seen in fig. I which gives distributions of nodule size in ie and $i_{1}$ lines inoculated with strain $\mathrm{A}$ and an effective strain CIF. The nodules on ie plants range in size up to $4 \mathrm{~mm}$., whereas with few cxceptions the more numerous nodules on $i_{1}$ plants are below $\mathrm{r} \mathrm{mm}$. in length. The ie plants in fig. I were taken at random from two sets of familics (fams. I54, I 57 and I 72-174). They show that great variation in nodulc size occurs cven among ineffectively responding plants, and also indicate an interesting relation which was obscured in the results for nodule number only: the ie effective segregants with $A$ arc aberrant in showing considerable numbers of small nodules in addition to an appreciable number of nodules over $2 \mathrm{~mm}$. in length. In fact, in size and in number, the distribution of nodules on these plants is equivalent to the summation of a normal effective nodulation and an ineffective nodulation characteristic of $i e$ ineffectives.

The genotypes of the effective plants with strain $\mathrm{A}$ are not known in these families. It was suggested above that the response of the recessive homozygote may be modified by a suppressor gene or genes, 


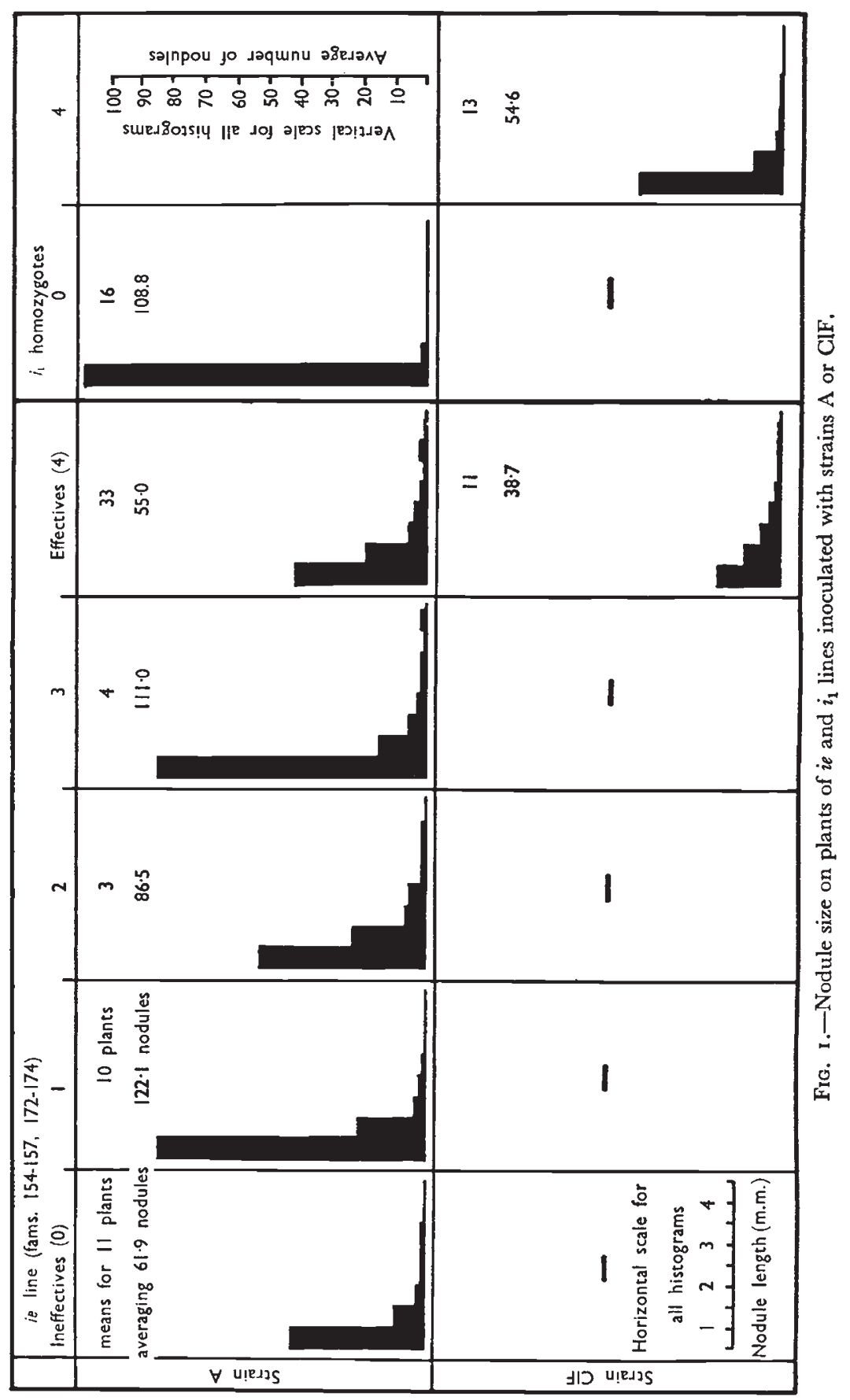


or that these effectives are themselves heterozygous for $i e$ or other factors, the genetical evidence being inconclusive. The distribution of nodule size on these effectives would be more readily understood in terms of a modification of the expression of the ie gene. Should effectiveness in these families be due in this way to a modifying factor or complex rather than to heterozygosis at the ie locus, it would appear that these genes are showing independent effects, the $i e$ homozygote giving rise to its particular distribution of nodules upon which is superimposed a normal effective type of nodulation due to the action of other genetic factors.

This interpretation requires that effective and ineffective nodulation by a single strain of bacteria may co-exist on the same root without apparent interference, on the basis that the amount of nitrogen fixed in the fewer effective nodules suffices to sustain normal growth and to allow at the same time the formation of ineffective nodules. The effective nodules would allow development of more foci of infection which would then give rise to a majority of ineffective nodules, the inhibitory influence of the fewer effective nodules being counteracted by their stimulating effect in promoting renewed growth.

In this way these plants would resemble normal plants inoculated with mixed effective and ineffective inocula which will give rise under certain conditions to both many small and few large nodules, as Nicol and Thornton (1942) have shown. This interpretation also suggests that the action of the modifying factors is to induce the effective response only in some nodules, not in all, possibly on certain parts of the root or determined by some physiological balance in the host. It was in fact observed that the development of the effective response was retarded in certain individual plants in which development of the effective response was strikingly correlated with the late formation of typically effective nodules on the root, as shown by the plant illustrated in plate $\mathrm{I}$, fig. $c$. The appearance of such plants suggests that a complete change in the activity of the new nodules occurred at about the time of formation of the fourth leaf. Plants of this kind occurred infrequently and sporadically. In the absence of any evidence (see below) that a change had occurred in the bacteria, the physiology of the host must in some way be involved. An investigation of the anatomy and cytology of these nodules is being undertaken.

A detailed analysis of nodule size and number is required to elucidate fully these relations, both from the genetical and physiological points of view; the determination of nodule size and number as well as effectiveness is more complex in these families than in the $i_{1}$ pedigree.

(v) The independent determination of the $\mathrm{i}_{1}$ and ie types of nodulation

Measurements of nodule length were made on effective and ineffective plants in $\mathrm{F}_{2}$ families derived from a cross between $i_{1}$ and $i e$ 
homozygotes ; the ineffective segregants for measurement were selected at random. The results are presented in histograms in fig. 2.

The effective plants showed a wide range of nodule size, occasional nodules measuring more than $5 \mathrm{~mm}$. in length. Variation in size was also considerable among some ineffectives but was much less on others, and on this basis a division of the ineffectives into two groups could readily be made as has been done in fig. 2; the arbitrary separation is made at $2 \mathrm{~mm}$. The first group contains plants with a type of nodulation typical of $i_{1}$ homozygotes and the second group

TABLE 5

Response of ie homozygotes (fams. 167-169) and unselected red clover with different strains of nodule bacteria

\begin{tabular}{|c|c|c|c|c|c|c|c|c|c|c|c|c|c|c|c|}
\hline \multirow{2}{*}{\multicolumn{4}{|c|}{ Strain }} & \multicolumn{5}{|c|}{ ie line response } & \multirow{2}{*}{$\begin{array}{c}\text { Mean } \\
\text { dry weight } \\
\text { (mgm.) }\end{array}$} & \multicolumn{5}{|c|}{$\begin{array}{l}\text { Unselected red clover } \\
\text { response }\end{array}$} & \multirow{2}{*}{$\begin{array}{c}\text { Mean } \\
\text { dry weight } \\
\text { (mgm.) }\end{array}$} \\
\hline & & & & 0 & I & 2 & 3 & 4 & & 0 & I & 2 & 3 & 4 & \\
\hline \multicolumn{4}{|c|}{ Experiment I (Rothamsted) } & & & & & & & & & & & & \\
\hline$f_{12}$. & . & . & . & I4 & I & $\cdots$ & $\ldots$ & $\ldots$ & $\mathrm{I} 6 \cdot 5 \pm \mathrm{I} \cdot 2$ & $\ldots$ & 14 & $\ldots$ & $\ldots$ & $\ldots$ & $20 \cdot 7 \pm 0 \cdot 9$ \\
\hline $\mathrm{HKC}$ & $\cdot$ & . & . & 9 & 3 & $\ldots$ & ... & $\ldots$ & I $7 \cdot 2 \pm I \cdot 5$ & $\ldots$ & 6 & 5 & $\ldots$ & $\ldots$ & $21 \cdot 7 \pm 0 \cdot 7$ \\
\hline $42 \quad$. & . & . & • & I 2 & 3 & $\ldots$ & ... & $\ldots$ & I $7.9 \pm 0.6$ & ... & I & 4 & 4 & I & $30 \cdot 5 \pm 3 \cdot 4$ \\
\hline Haldon I & . & . & • & I 2 & $\ldots$ & I & 3 & $\ldots$ & I $9 \cdot 4 \pm$ I.3 & $\ldots$ & $\ldots$ & 2 & 5 & 6 & $44 \cdot 8 \pm 4 \cdot 7$ \\
\hline Hannay 7 & • & . & • & 3 & I & 3 & I & 6 & $30 \cdot 9 \pm 4 \cdot I$ & $\ldots$ & $\ldots$ & $\ldots$ & 2 & Io & $50 \cdot 5 \pm \mathrm{I} \cdot 8$ \\
\hline ClF . & . & . & • & I & I & $\ldots$ & 4 & 6 & $35 \cdot 0 \pm 4 \cdot 4$ & $\ldots$ & $\ldots$ & $\ldots$ & 2 & I I & $48 \cdot 5 \pm 2 \cdot 7$ \\
\hline Strain A & • & · & • & 8 & ... & ... & I & 3 & $25 \cdot 2 \pm 4 \cdot 4$ & $\cdots$ & $\cdots$ & $\cdots$ & I & 4 & $49 \cdot 0 \pm 8 \cdot 5$ \\
\hline \multicolumn{4}{|c|}{ Experiment 2 (Canberra) } & & & & & & & & & & & & \\
\hline $\mathrm{HKC}$ & . & . & . & 7 & $\cdots$ & $\cdots$ & $\cdots$ & & $3 \cdot 6 \pm 0 \cdot 1$ & 7 & $\ldots$ & $\ldots$ & $\ldots$ & $\ldots$ & $4 \cdot 4 \pm 0 \cdot 3$ \\
\hline SU. $297 / 3$ & . & . & . & I9 & I & I & ... & $\ldots$ & $9 \cdot 4 \pm 2 \cdot 9$ & 3 & 5 & 10 & 3 & I & $33 \cdot 7 \pm 4 \cdot 3$ \\
\hline Haldon I & . & . & . & 22 & $\ldots$ & $\ldots$ & $\ldots$ & ... & $3 \cdot 8 \pm 0.2$ & $\ldots$ & $\ldots$ & 3 & I I & 8 & $64.5 \pm 3 \cdot 8$ \\
\hline ClF . & . & . & $\cdot$ & 6 & I & 2 & 8 & IO & $49 \cdot 9 \pm 6 \cdot 6$ & $\ldots$ & $\ldots$ & $\ldots$ & 6 & I 5 & $73 \cdot 2 \pm I \cdot 5$ \\
\hline Strain A & . & - & · & 20 & 2 & I & 2 & 2 & I0.9土3.9 & $\cdots$ & ... & $\cdots$ & I & I 3 & $63 \cdot 4 \pm 2 \cdot 3$ \\
\hline
\end{tabular}

those typical of ie homozygotes, suggesting that the plants in the first group represent the $i_{1}$ segregants and those in the second group the ie segregants.

The contrasted types of nodulation found in these ineffectives, in about equal numbers, gives additional support for the unifactorial nature of these genes. Other factors for ineffectiveness may be segregating in these families as suggested above, although there is no evidence from nodule measurement of other distinctive size distributions than those which can be attributed to $i_{1}$ or $i e$ homozygotes, neither can the $i_{1}$, ie double recessive be identified.

\section{(vi) Response of ie homozygotes with other strains of bacteria}

The reactions of ie plants to inoculation with a number of bacterial strains were examined in two experiments. The results are given in table 5 in terms of the number of plants falling into each category of response, as well as in mean plant dry weight for each combination 


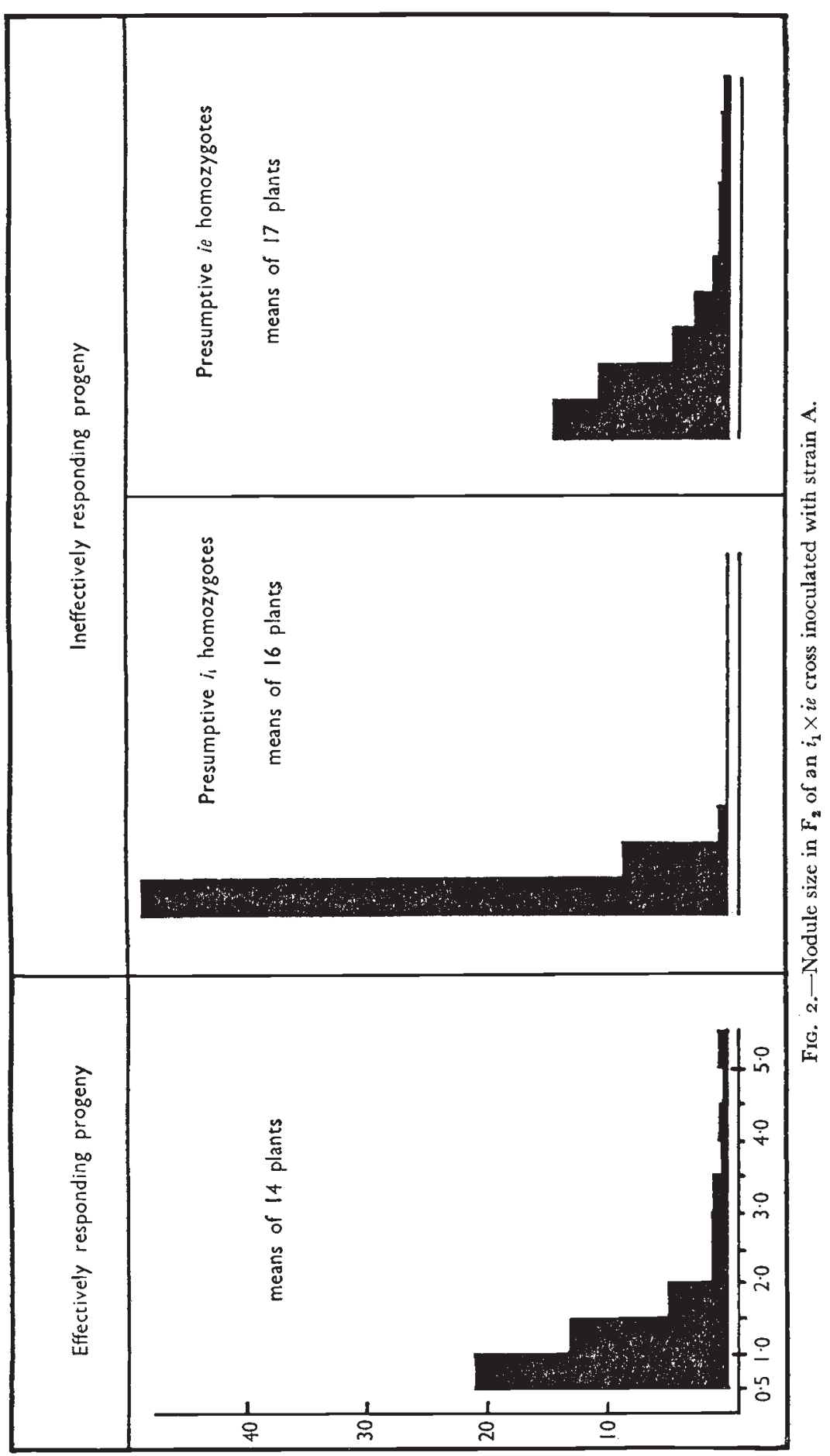


of strain and host; uninoculated clover is included as control for bacterial strain. The bacterial strains employed were strains A, GlF and Hannay 7 as effectives, strains Haldon I, SU.297/3 (Baird, I955) and Rothamsted 42 as intermediates, and Rothamsted strains HKC and $f_{12}$ as ineffectives (the strain $f_{12}$ is a mutant ineffective derived from strain $\mathrm{A}$ and has been found to give a generally similar response to the standard ineffective strain $\mathrm{HKC}-\mathrm{Nutman}, \mathrm{I946)}$. The results of the experiments are in agreement and show that the $i e$ line responds in an almost completely ineffective manner with all strains of less effectiveness than A. On the other hand, with the two most effective strains the ie homozygotes are mostly effective, although they do not reach the degree of effectiveness found on unselected material.

TABLE 6

Response of families in the ie line which derive from a plant responding ineffectively with strain $\mathrm{ClF}$

\begin{tabular}{|c|c|c|c|c|c|c|c|c|c|c|c|c|c|}
\hline \multirow{3}{*}{ Family } & \multirow{3}{*}{ Cross type } & \multicolumn{12}{|c|}{$n$ ssponse of progeny } \\
\hline & & \multicolumn{6}{|c|}{ with strain $\mathrm{A}$} & \multicolumn{6}{|c|}{ with strain $\mathrm{ClF}$} \\
\hline & & 0 & I & 2 & 3 & 4 & $\begin{array}{l}\text { Corrected } \\
\text { ratio }\end{array}$ & o & 1 & 2 & 3 & 4 & $\begin{array}{l}\text { Corrected } \\
\text { ratio }\end{array}$ \\
\hline 220 & I $\underset{\text { (with ClF) }}{(\text { with }}$ A) $\times I$ & 13 & 3 & 5 & 5 & 4 & $14.5: 15.5$ & 5 & I & 4 & 16 & 3 & $5.5: 23.5$ \\
\hline 221 & , & 24 & $\ldots$ & I & $\ldots$ & $\ldots$ & $\cdots$ & 14 & 2 & 2 & 4 & $\ldots$ & $15: 7$ \\
\hline
\end{tabular}

It is of interest that with Hannay 7 and $\mathrm{ClF}$ the ie homozygotes do not respond uniformly; some continue to show a fully ineffective response whereas others are quite effective. This suggests that the suppression of the interaction between the ie gene and factors in the bacteria leading to ineffectiveness, is not only a function of bacterial strain but also involves other host determinants, which in this instance may be simple and dominant $\left(\chi^{2}(\mathbf{1}: 3)=\mathbf{I} \cdot \mathrm{o}\right.$, n.s. $)$. To examine the possibility of further selection towards ineffectiveness in the ie line, a plant responding ineffectively with $\mathrm{ClF}$ was crossed with two normal ineffectives (inoculated strain A). These families were tested against strains $\mathrm{A}$ and $\mathrm{ClF}$.

The results of this test given in table 6 show that the two families behaved differently; one continued to show about one quarter ineffectives with ClF ( $\chi^{2}=0.56$ n.s.), and also segregated I : I with strain $\mathrm{A}$. The other responded in a largely ineffective manner with ClF. This result clearly indicates that simple genetic factors in the host determine whether the interaction between the ie gene and the bacteria will lead to ineffectiveness or effectiveness. It is also evident from the parallel family differences with strain $A$ that these factors are non-specific. 
This absence of a high degree of specificity with respect to strain is in marked contrast to the results found for $i_{1}$ where the specificity with respect to strain $\mathrm{A}$ was complete.

(vii) Response of ie homozygotes with strain $A$ re-isolates

In tests made with ie line plants no opportunities have arisen for the isolation of mutant strains of bacteria from single large effective nodules on plants otherwise bearing only large numbers of small nodules, as occurred with the $i_{1}$ line. As noted above $i e$ plants tended to produce numbers of large nodules as well as ones of medium or small size. Isolations were made from the largest and smallest nodules available. Included with these were isolates from large nodules on plants bearing larger nodules on the younger parts of the root instead of on the crown, a type of nodulation which occurs infrequently on the ie line and is illustrated in plate I, fig. $c$. Strain A was also passaged repeatedly through the $i e$ host and then tested for effectiveness. Isolates were taken at each passage from a number of nodules to increase opportunities for adaptation.

The response of these various classes of re-isolate was examined on ie plants (including families segregating small numbers of effectives) with the results set out in table 7 . At the same time tests were made with re-isolates from nodules on $i_{1}$ plants, two of which (substrains

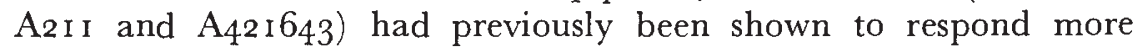
effectively with $i_{1}$ plants.

No consistent differences appeared in the effectiveness of any of these re-isolates with ie plants. The strain A2II appeared in the first test to be a little more effective than A, but this was not confirmed in the later experiments. In view of the high degree of specificity of the effective response of A2 I I with $i_{1}$ and its dependence also upon factors other than $i_{1}$ (see Nutman, I954b, p. 54), the result obtained was not surprising.

The tests of the new re-isolates from ie nodules were also negative as far as the detection of any alteration in effectiveness was concerned, whether they were derived from effectively or ineffectively responding plants, or from large or small nodules, or had been carried through a number of plant passages.

The plants grown at Canberra, under conditions of higher temperature and light intensity, gave a more marked ineffective response than those in the Rothamsted experiments. This also appears in the dry weights recorded in the two experiments in table 5, where, however, the comparison between bacterial strains is not affected. The low final dry weights of the ineffective plants in the warmer environment may be due to higher respiratory losses.

\section{GENERAL DISCUSSION}

(i) Genetics of symbiotic effectiveness

Earlier results have shown that effectiveness of the host's response 
in symbiosis may be determined by primary genes and by associated modifying factors, each of which interact specifically with factors in the bacterial strain.

TABLE 7

Response of ie homozygotes with re-isolates of strain $A$ taken from nodules on $i_{1}$ or ie homozygotes

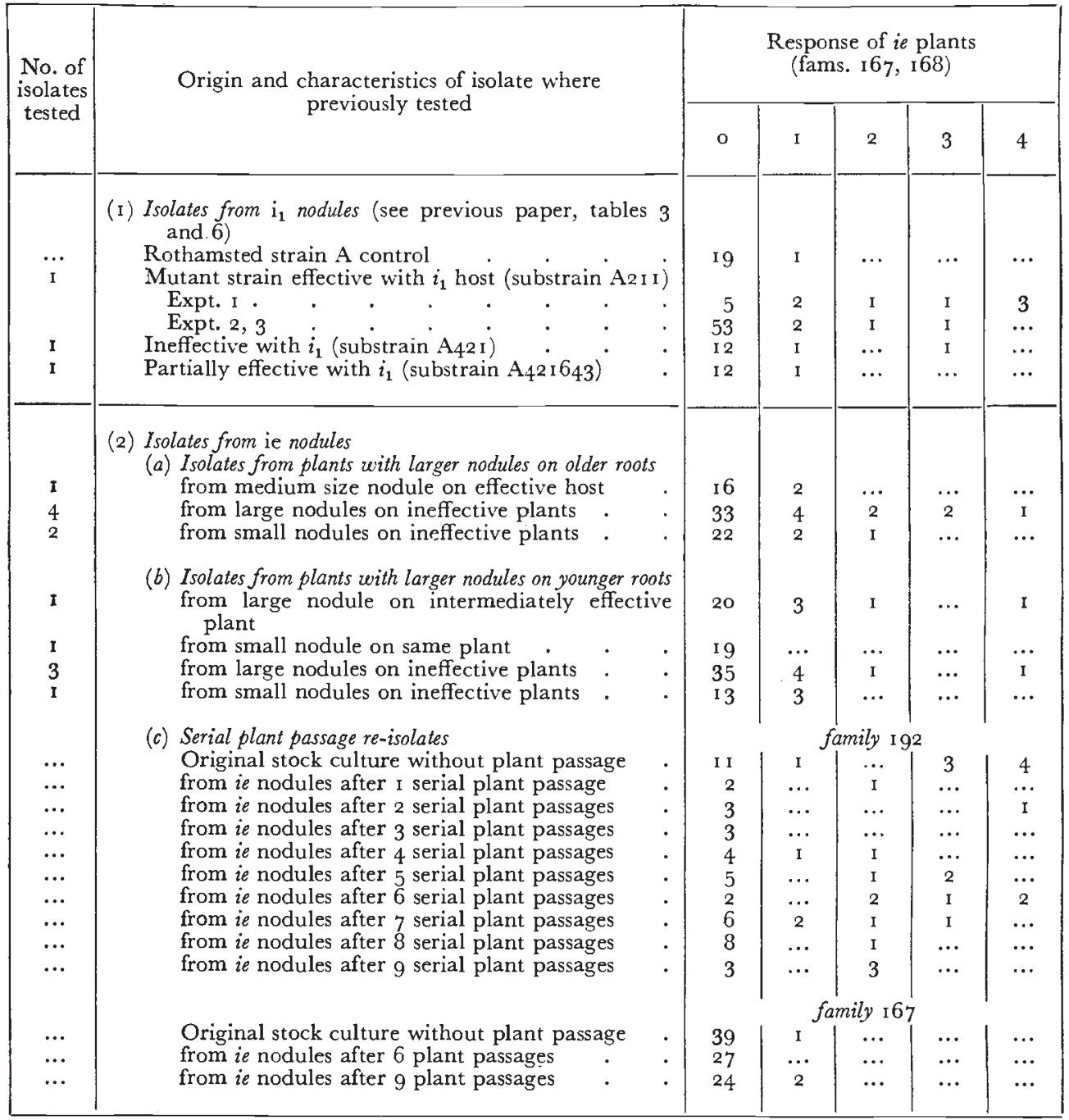

This interpretation receives support in the present paper by the identification of a second primary gene for ineffectiveness, $i e$, and by the suggestion that its action may also be influenced by modifiers. The gene ie is, however, largely unspecific in its interaction with bacterial strain, as also is the action of modifying genes.

The independent action of these genes is inferred from a consideration of the divergent types of nodule ascribed to each of them (fig. 2), and by their differing specificities with regard to bacterial strain. 
Although the ineffectiveness induced by $i_{1}$ or $i e$ appears to be due to effects on the tissue of the nodule containing the bacteria, and in which nitrogen is presumed to be fixed, the extent to which these effects involve the uninfected growing point of the nodule differs decisively. With $i_{1}$ the nodule meristem is immediately involved so that the nodule makes no growth and remains very small. With ie, on the other hand, the processes taking place in the infected tissues do not involve the nodule meristem to the same extent so that growth continues and larger nodular structures are produced.

The relationship between nodule size and abundance conforms broadly to previous experience : the larger the average nodule size the smaller the number of infections sustained. An explanation of this relationship in terms of the morphogenesis of nodules from incipient lateral root initials and their inhibition by the activity of nodule and root growing points has been presented elsewhere (Nutman, I 948 , I952). The correlation between abundant nodulation and small nodule size in much of this material gives additional support for this theory.

The modes of action of the modifiers presumed to influence the genes $i_{1}$ and $i e$ also show interesting differences. The modification of the action of $i e$ with strain $A$ appears to operate by inducing the effective response in a proportion only of ie nodules, the remainder continuing to show ineffective morphology and function. As a result, ineffective nodulation is able to continue on a root system which is expanding on account of the presence of effective nodules. Consequently a much larger number of nodules is produced than can be formed on a wholly ineffective plant. An investigation of the physiology of this situation may reveal the presence of mobile substances which stimulate or inhibit effectiveness.

In contrast the factor $m_{1}$ has been shown to nullify completely the effect of the $i_{1}$ gene so that relatively few nodules of average size are formed and typically ineffective nodules are absent (table 7 of the previous paper, fams. 138, I39). In this connection it may also be noted that the nodules on effective ie plants inoculated with strain $\mathrm{ClF}$ were typically effective in distribution and size (table 4 and fig. I). If effectiveness in these plants is determined by supplementary dominant factors, as seems probable from the data in table 6, such factors act like $m_{1}$ upon the plant as a whole. Further work may show that modifying factors are of greater significance in the development of symbiosis than the primary genes, although the latter individually appear to show the most striking effects because without them the modifying influences cannot be detected.

(ii) Viability of ineffective selections

The development of ineffectiveness in the ie material was not correlated with any obvious characteristics in the young seedling plants before nodulation commenced. Moreover, homozygotes 
inoculated with the very effective strains ClF or Hannay 7 continued to develop in a normal manner. Nevertheless considerable difficulty was met in raising the homozygous ie plants, inoculated with strain $\mathrm{A}$, to maturity. Only nine ineffectives survived out of a total of more than 60 planted into soil and of these some failed to flower. This could not be attributed to their initial small size and $\mathrm{N}$-starved condition since other ineffective selections and plants inoculated with ineffective strains were readily grown into mature plants.

In the $i_{1}$ line any weakening effect of the homozygote was not at first noticed. Of the nine ineffectives of the original family in the $i_{1}$ pedigree (Nutman, r $954 b$, table $\mathrm{I}$, fam. 8I) which were planted into soil, only one was lost. Similarly in families derived directly from family 8I no considerable losses occurred. After outcrossing, however, the semi-lethal effect of the homozygote was very evident and of fourteen selected plants only three survived.

Why are these recessives so inviable? The results recall those obtained for the differential survival of plants resistant to infection by nodule bacteria ( $r$ homozygotes) in the presence and in the absence of a specific cytoplasmic factor ( $\sigma$ cytoplasm) previously described (Nutman, 1949). It was there shown that $r$ was lethal except in the presence of $\sigma$ cytoplasm. This cytoplasm was also shown to have a similar effect on the viability of a number of abnormal seedlings.

It is probable that the difference in survival of the $i_{1}$ homozygotes before and after outcrossing was due to the same cytoplasmic factor because one of the original parents $\left(\mathrm{P}_{1}\right)$ was a daughter of a resistant plant, and was shown to contain $\sigma$ cytoplasm by independent breeding tests. On outcrossing this cytoplasm was lost and the viability of the ineffectives decreased. Although the poorer longevity of ie plants compared to $i_{1}$ ineffectives before outcrossing may be similarly due to disturbances in metabolism of cytoplasmic origin, there was no evidence in the $i e$ pedigree of maternal effects which might be associated with differences in cytoplasmic components.

\section{SUMMARY}

I. A recessive gene $(i e)$ is described which confers symbiotic ineffectivencss upon plants inoculated with certain effective strains of nodule bacteria.

2. The ineffective response in ie hosts is not markedly specific to bacterial strain; with outstandingly effective strains a mixed response occurs, with others the response is uniformly ineffective.

3. No variants of the test strain A have been found with which ie homozygotes are effective.

4. ie nodules produced by strain A vary in size and abundance from plant to plant.

5. Modification of the ie response with strain A by other host factors is tentatively inferred from the genetical results. This modification does not appear to suppress fully ie type nodulation with strain A. 
FIGs. $a$ and $b$.-Ineffectively responding $i e$ plants inoculated with strain A.

FIG. c.-Modification of the ineffective response in $i e$ homozygotes with strain $A$ by other hosts factors acting on younger nodules. Change in response in plant " $c$ " occurs at about $4^{\text {th }}$ leaf stage. Note correspondence between changes in top growth and nodule pattern.

FIG. d.-Effectively responding ie heterozygote. 


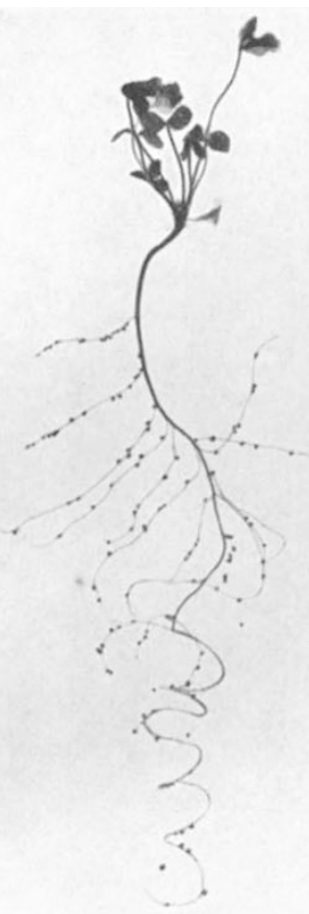

FIG. $a$

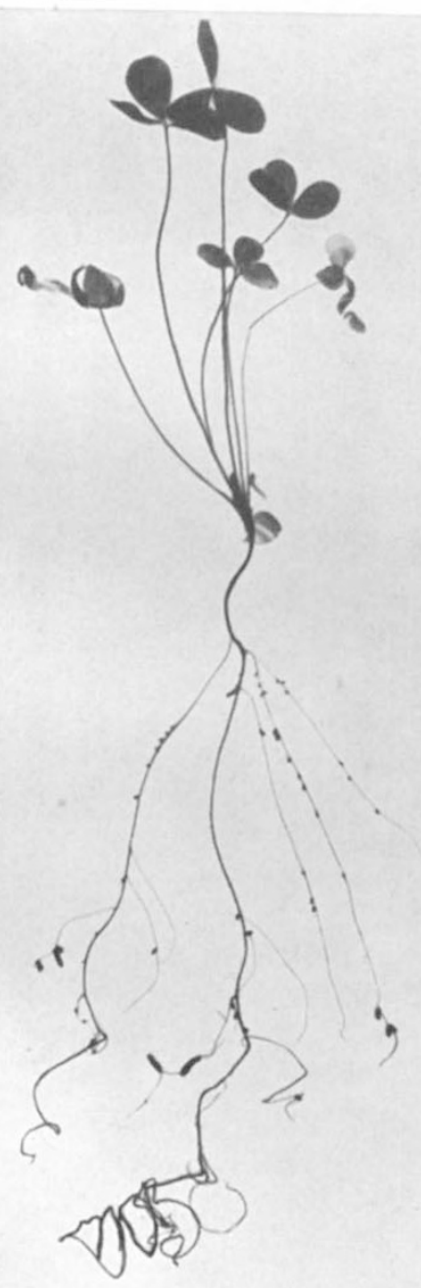

FIG. C

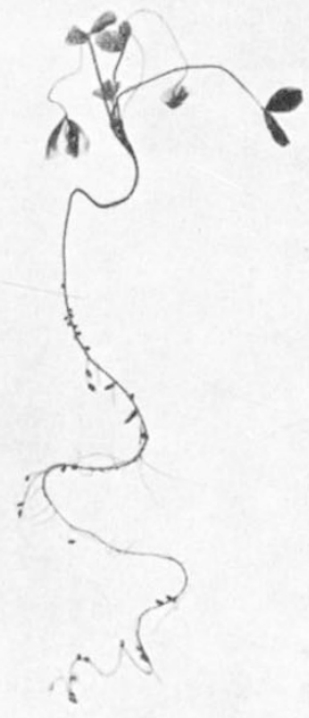

FIg. $b$

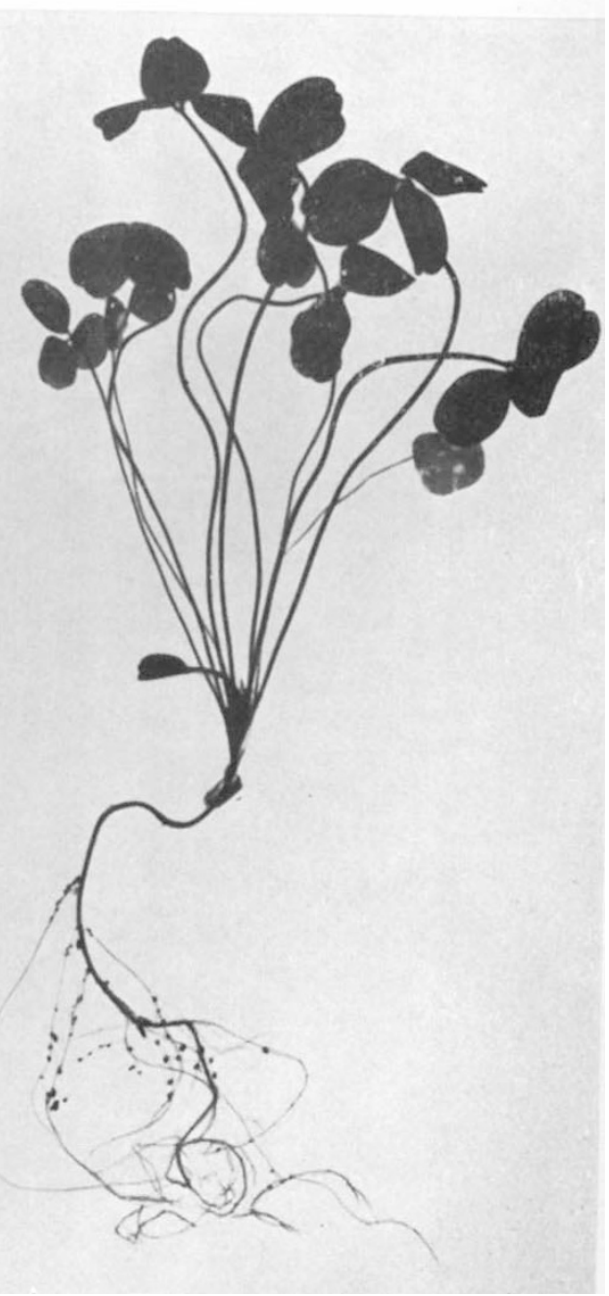

FIG. $d$ 
6. Ineffectiveness due to ie differs from that due to the factor $i_{1}$ previously described in $(a)$ the size and numbers of nodules formed, (b) specificity with respect to bacterial strain, and $(c)$ the mechanism of its suppression by other host factors. The genes $i_{1}$ and $i e$ are neither identical nor allelic.

7. The factor ie decreases the vitality and longevity of the host and affects flowering. Possible reasons for this are discussed.

Acknowledgments.-For helpful criticism the author is grateful to $\mathrm{Dr} \mathrm{H}$. G. Thornton, F.R.s., and to colleagues at Canberra, in particular Dr F. H. W. Morley. Thanks are also due to Miss Joan Crawley, Mr M. Shaw and Mrs A. H. G. C. Rijven for technical assistance, and to Mr J. Brockwell for permission to quote results obtained in the plant passage experiment.

\section{REFERENCES}

BAIRD, K. J. I955. Clover root nodule bacteria in the New England region of New South Wales. Aust. 7. Agr. Res., 6, i 5-26.

NICOL, H., AND THORNTON, H. G. 1942. Competition between related strains of nodule bacteria and its influence on infection of the legume host. P.R.S., B, I3O, 32-59.

NUTMAN, P. s. 1946. Variation within strains of clover nodule bacteria in the size of nodule produced and in the "effectivity" of the symbiosis. F. Bact., 5 I, $4 \mathrm{II}-432$.

NUTMaN, P. S. 1948. Physiological studies on nodule formation. I. The relation between nodulation and lateral root formation in red clover. Ann. Bot. Lond., I2, 81 - -96.

NUTMAN, P. S. 1949, 1952, I $954 a$ and $b$ : see Part IV.

WRIGHT, s. 1922. Coefficients of inbreeding and relationship. Amer. Nat., 56, 330-338. 